\title{
Southern Green Cultural Criminology and Environmental Crime Prevention: Representations of Nature Within Four Colombian Indigenous Communities
}

\author{
David Rodríguez Goyes ${ }^{1}$. Mireya Astroina Abaibira ${ }^{1} \cdot$ Pablo Baicué ${ }^{\text {. }}$ \\ Angie Cuchimba ${ }^{1}$. Deisy Tatiana Ramos Ñeñetofe ${ }^{1} \cdot$ Ragnhild Sollund $^{2}$. \\ Nigel South ${ }^{3} \cdot$ Tanya Wyatt $^{4}$
}

Accepted: 12 July 2021 / Published online: 19 July 2021

(C) The Author(s) 2021

\begin{abstract}
This exploratory study develops a "southern green cultural criminology" approach to the prevention of environmental harms and crimes. The main aim is to understand differing cultural representations of nature, including wildlife, present within four Colombian Indigenous communities to evaluate whether they encourage environmentally friendly human interactions with the natural world, and if so, how. The study draws on primary data gathered by the Indigenous authors (peer researchers) of this article via a set of interviews with representatives of these four communities. We argue that the cosmologies that these communities live by signal practical ways of achieving ecological justice and challenging anthropocentrism.
\end{abstract}

\section{Introduction}

In $1922,{ }^{1}$ German anthropologist Franz Boas, published a study about Indigenous peoples ${ }^{2}$ which at the time - a period dominated by Darwinist ideas-seemed progressive and revolutionary: he asserted that all "races" had the same physical and mental capabilities to

\footnotetext{
1 Reprinted 2012. ance among the communities with which we have worked.

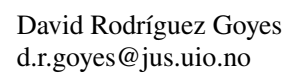

2 There is a wide-ranging discussion about how to refer to Indigenous peoples, and both Indigenous and non-Indigenous commentators have used myriad terms to refer to them. Based on Columbus' mistake, during the sixteenth, seventeenth and eighteenth centuries, missionaries, anthropologists and others used the terms "Indians" and "savages." Both terms are widely recognized as unacceptable for their degrading and racist connotations (Younging 2018). Currently, the term "Indigenous" "is gaining currency," mainly, because "it is used in the UN Declaration on the Rights of Indigenous People" (Younging 2018: 64). This term is, however, also problematic because it collapses various cultural characteristics into an undifferentiated mass (Apaza Huanca 2019; Heydon 2019). We use it here for its conceptual usefulness and its accept- 
develop. He argued that the "higher level of civilisation and development" of Western societies compared to "primitive" ones were a result of conjunctural hindrances experienced by the latter. Boas saw the superiority of the West as a reflection of the physical transformations and profit-motivated endeavors that turned "inhospitable forests into fertile fields" and led to "mountain fastnesses ... yielding their treasures"-with "fierce animals" that obstructed "progress ... being exterminated" - while others of more utility were "made to increase a thousand-fold" (Boas 2012: 1). By contrast, for Boas (2012: 236), the principal expression of the "primitive man's" cultural inferiority and atavism was "a peculiar connection that is believed to exist between a certain class of objects, generally animals, and a certain social group": in other words, appreciation and respect for non-humans and other humans.

We now know that the activities that for Boas marked the superiority of the "white man" have, in fact, led the world to an environmental crisis and, over the past three decades, these anthropocentric and androcentric practices and beliefs have been criticized by individuals and organizations around the world. Notably, the United Nations Development Programme (UNDP) declared that one of the main environmental challenges of the moment is the unprecedented level of biodiversity loss resulting from land degradation, but also from "poaching" and trafficking of "wildlife" (UNDP n.d.). ${ }^{3}$ Consequently, the UNDP has called for the identification of alternative approaches to the currently dominant ways in which humans relate to other components of nature, with the aim of creating and encouraging opportunities for providing income without deepening the present environmental crisis. Under this new framework, the activities that Boas considered cultural atavism have become desirable solutions.

Green criminology - the "loose framework or set of intellectual, empirical and political orientations toward problems (harms, offences and crimes) ... related to the environment, different species and the planet" (South et al. 2013: 28)—has, since its inception, devoted its efforts to studying and denouncing environmentally destructive practices, but it has also urged efforts to find preventative measures to address green crimes and harms. These calls and proposals have ranged from the practical to the propositional. Examples could include the application of traditional crime prevention methods (Brisman and South 2015) and the development of a "restorative environmental justice praxis" (Biffi and Pali 2019). At a different level, inspired by peacemaking criminology and based on the human dynamics that lead to cooperation and trust, McClanahan and Brisman (2015: 425) have called for a "peace treaty" that leads to an "ecocentric approach to human-environment relationships," and Amster (2019) has promoted a proactive and constructive peacebuilding to end destruction of the planet.

In this article, we explore human relationships with the environment by showing how the environmental representations and associated practices of four Colombian Indigenous communities present a contrasting approach to that which is dominant in the Global North. We also inquire whether those Indigenous representations lead to environmentally friendly practices, and if so, why. By presenting an overview of the universes of meanings behind the environmental practices of those four Colombian Indigenous Peoples, our intention is

\footnotetext{
3 While the terms, "poaching" and "wildlife," are anthropocentric, and their widespread use is not in keeping with the spirit of the discussion presented here, we have retained them for the sake of simplicity. We note, however, that "poaching" implies that killing or taking nonhuman animals is acceptable if it is undertaken within the law, and that "wildlife" suggests that nonhuman animals are a single, homogeneous group, which fails to recognize the interests of individual animals.
} 
to suggest a cultural crime prevention approach to green crimes. Our hope is to illuminate and make internationally visible some cultural frameworks that encourage and enhance mutually beneficial and respectful relations with nature. We argue that there is an inextricable link between saving Indigenous cultures and finding ways to achieve ecological justice and prevent green crimes.

In the first part, "Crime prevention and green criminology," we provide a brief overview of green criminological approaches to crime prevention. Recognizing that this collaborative study has several points of origin, reflecting the biographies of the various authors, and that it is also a project drawing on different theories and adopting a mixed methods approach, we dedicate the subsequent two parts to, first, outlining the conceptual and theoretical frameworks on which we have drawn ("Southern green cultural criminology") and then to describing our methods, explaining how we have applied a "peer research" approach to gathering original data, which has been supplemented by drawing on secondary sources ("Methods"). In the part entitled "Context: The Colombian Indigenous Peoples," we introduce the Indigenous communities involved in our project. In the "Findings" part, we suggest that the cultural representations of nature that we present-which we refer to as "environmental ontologies" because they deal with the form and reality of nature (Effinghan 2013)—underpin environmentally protective behaviors because they have two main traits: (1) they connect the well-being of humanity with the well-being of all other beings on Earth; and, (2) their cosmologies explain the importance of and consider sacred all components of nature, not just human beings (Descola 2005). We then elaborate on how these traits could lead to practical ways of achieving ecological justice by challenging anthropocentrism and conclude by highlighting the missed opportunity to learn from existing knowledge. At present, international political and economic leadership places faith in the future promises of science (see, e.g., Rees 2018), while Indigenous environmental ontologies that offer a template for a cultural approach to reduction of environmental harms and crimes are ignored and are at risk of disappearing.

\section{Crime Prevention and Green Criminology}

"Crime prevention" refers to the "efforts to prevent crime or criminal offending in the first instance —before the act has been committed" (Welsh and Farrington 2012: 3). Most commentators agree on classifying crime prevention approaches into five categories: (1) "deterrence through law enforcement and adjudication," which relies on "the threat of apprehension, prosecution, and punishment" (Rohe 2012: 108); (2) welfare crime prevention, which "seeks to address underlying social problems associated with crime, such as lack of job opportunities" (Rohe 2012: 108); (3) developmental crime prevention that "postulates that criminal offending in adolescence and adulthood is influenced by 'behavioural and attitudinal patterns that have been learned during an individual's development"' (Farrington et al. 2012: 8); (4) community crime prevention, which builds on "the community capacity to address crime and crime-related problems" (Rohe 2012: 108); and (5) environmental-situational crime prevention, which "seeks to reduce criminal opportunities though target hardening, surveillance, and environmental management" (Rohe 2012: 108).

Green criminology has focused mainly on suggesting the application of environmentalsituational crime prevention strategies. For instance, Hill (2015) proposes the use of computer modeling to predict the behaviors of poachers and wildlife with the aim of being able 
to modify a scene in order to disrupt poacher activity. The related field of conservation criminology proposes relying on "natural resource management, and risk and decision sciences" (McGarrell and Gibbs 2014: 5-6) to prevent environmental crimes. Green criminologists, however, have devoted far less attention to the cultural aspects of developmental and community-based crime and harm prevention approaches that could be drawn from the narratives of members of communities whose lives and experiences are entwined with nature.

To start developing such a cultural crime prevention approach, we gain inspiration from other disciplines that champion the idea that some of the productive environmental practices of Indigenous communities are environmentally more sound than Western ones, and that they could be used more broadly to encourage prevention of ecological deterioration. Professionals from the natural sciences, particularly biology and ecology (Datta 2019; Geilfus 1994), engaged in exploring the relationships between human beings and the natural environment, have identified some of the behaviors of various Indigenous communities as far less environmentally harmful than those encouraged by modern Western society and the dominant production system that results in ecological disorganization and destruction. Similarly, some social scientists (Kassam 2009; Norberg-Hodge 2009) and philosophers (Vetlesen 2019) have argued that the Western world has much to learn from the harmonious ways in which many Indigenous peoples around the world coexist with their natural environment based on the guidance of their Indigenous cosmologies.

Having established this line of argument, it is, nonetheless, important to resist romanticization and uncritical adoption of an image of Indigenous peoples as idealized protectors of nature (see, e.g., Tsering 2008), given that some Indigenous communities have engaged in practices antithetical to ecological and species justice. For instance, a Mayan community in the Yucatan peninsula of Mexico annually organizes its kots kaal pato festival during which children capture iguanas and endangered opossums, then place them inside a piñata which villagers take turns beating until the nonhuman animals are dead (Borges and Martín 2015). The festival ends with a contest to pull the heads off ducks tied to a scaffold (Borges and Martín 2015). Other examples could be provided of instances in which Indigenous communities engage in distancing from or lack of respect for nature. These seem to be exceptions (Borges and Martín 2019), however, and none of the Indigenous peoples included in this study engages in similar practices.

Furthermore, neither the existence of practices, such as the kots kaal pato, among Indigenous factions nor the fact that Indigenous communities-like any other-are far from perfect, undermine the point that most Indigenous retain a close cultural relationship with nature and that their traditions treasure - and transmit between generations - a wide-ranging repertoire of their own representations of nature that are conducive to protective behaviors (Verne, 2019). For community members whose actions are destructive and damaging to nature, breaking the bounds of cultural rules and expectations, it should also be noted that some of the traditions relating to justice and punishment enacted in response might conflict with some "Northern"/ "Western" post-Enlightenment norms. Our intention here is to accept that there will be matters about which disagreement and dispute will be clear, but to focus on the positive ways in which community celebrations and representations of nature are, in themselves, the basis of a cultural approach to prevention of environmental harms and crimes.

Before presenting the findings of our study, we explain in the next parts the conceptual, methodological, and theoretical tools we used to map such representations within four Colombian Indigenous communities. 


\section{Southern Green Cultural Criminology}

In this article, we aim to contribute to the development of a southern green cultural criminology, following Goyes's (2019: 11) call to be "attentive to the dynamics and contexts of the Global South" and to the "epistemological power of the marginalised, impoverished and oppressed." Previous work within criminology and the sociologies of deviance, conflict and rights has explored the significance of exploitation and expression, as well as resistance and ritual, at the "periphery" or in the "Global South" (Coomber and South 2004; Goyes and South 2017). Indeed, Brisman and South (2020, in press) have already proposed a "green cultural criminology of the south," which seeks to extend "green cultural criminology" (which originated in the Global North) to the Global South. Meanwhile, in this article, we propose a "southern green cultural criminology," which we consider an extension of southern green criminology. This developing "southern" perspective has been stimulating (Brisman et al. 2018; Carrington, Hogg and Sozzo 2016; Goyes 2018; Sollund and Runhovde 2020; White 2018), not least in suggesting we should make the effort to learn from the knowledge of those who are usually not part of the criminological conversation-in this case, Indigenous peoples. A key concept within the idea of a southern green criminology is the progress parabola (Goyes 2019). This is a notion that (1) critiques the idea that Western technology will save "primitive societies" by speeding up their development; and that (2) argues that we can find solutions to the environmental crises generated by the Western development project by learning from the practices and beliefs of "primitive societies." The implication of the progress parabola is the need for a rapid and radical shift in our individual and societal behaviors toward nature, as well as our understandings of the world. This concept resonates with Cunneen and Tauri's (2017: 10) first principle of Indigenous criminology, namely, "the belief in the ability of Indigenous peoples to carry out empirical research that will result in meaningful outcomes for their communities."

The aim, here, is to fuse together the propositions of a southern green criminology with the influences of green cultural criminology (Brisman and South 2013, 2014, 2020). The latter seeks to explore how representations of the "environment" (broadly defined), transmitted in both news and popular culture, influence and shape attitudes and behavior, including protective and destructive human actions. While a green cultural criminology accepts that undoubtedly the economic interests of transnational corporations are one of the main reasons why many capitalist production practices are pursued regardless of evidence of their environmentally destructive consequences (Crook et al. 2018; Higgins 2010; MacManus 2016; South 2007; Stretesky, Long and Lynch,2014; Wyatt 2015), it argues that there are also cultural factors of importance here.

In this article, we argue that Indigenous environmental ontologies offer guidance on ways of living that could prevent or diminish environmentally harmful practices or crimes. We acknowledge, however, that any analyses of Indigenous cultures by outsiders may be problematic (Hall 1992; Said 1978). Consequently, we aim to avoid imposing Northern/ Western "ways of seeing or imagining" on the lived realities of others, remembering the importance of symbolism, multiple meanings, and cultural cosmological ambiguity (Apaza Huanca 2019; Frank 2010; Sandberg et al. 2015). We suggest that by making Indigenous environmental ontologies internationally visible, preventing their disappearance, and committing to the preservation of Indigenous memories, an important counter-narrative to the dominant and omnipresent cultural messages of consumer capitalism could be presented and promoted. This would form the basis of a crime prevention strategy grounded in an alternative cultural vision of living harmoniously with nature. 
The idea of an "alternative" worldview and economic approach based on an exchange partnership with the environment rather than on extraction and exploitation (Wilson and Stammlet 2016) is sorely needed when the most significant and influential elements of life in growth economies continually prompt us to engage in environmentally damaging practices, and relatively few aspects of life dominated by consumerism invite us to take care of nature (Brisman and South 2014).

\section{Methods}

This study is an empirical exploration of cultural representations of nature preserved and used within the communities of the Barí, Nasa, Ticuna and Uitoto Indigenous peoples, selected on the basis of two criteria. First, the technique of maximum variation sampling to find "the full range of extremes in the population" (Adams and Lawrence 2019). As elaborated below, the Bari people remained isolated until 1975, successfully rejecting any kind of external interference until then. Their culture is, therefore, less influenced by Western values. The Nasa people, however, were less successful in resisting and rejecting the many intrusions they have faced since the Spanish invasion. Nonetheless, despite many forms of cultural interference, the Nasa did manage to protect their traditions and values. Finally, the Ticuna and the Uitoto have had many contacts with colonizers and, due to threats to their survival, they were, over time, coerced into yielding their traditional values and embracing various imposed Western practices and beliefs. These four Indigenous groups provide us with a full range of communities in states of isolation, resistance, and domination. Second, we adopted a convenience sampling approach to recruit "volunteers or others who are readily available and willing to participate" (Adams and Lawrence 2019: 123) —in our case, as researchers.

The core research theme, therefore, is Indigenous representations of nature and their relationship with protective or destructive environmental behaviors. To explore this relationship, we drew on primary and secondary data from four different sources. As primary data, ${ }^{4}$ we relied on participatory observation of the actual practices of these four communities, regarding their everyday relationships with the elements of nature, and on thirty interviews with the "elders" 5 of the four communities. The observations took place over periods of between four days and one week. The project design drew upon "peer research methodology" (see Lushey and Munro 2015), but there is a limit as to how much peer researchers can accomplish because they are not "salaried full-time academic researchers" Lushey and Munro 2015: 534). As such, we combined the peer methodology with secondary data gathering. This secondary data gathering relied on (1) the texts "outsiders" have written about the culture of the Barí, Nasa, Ticuna and Uitoto communities; and (2) recordings of the Indigenous "mingas"- -yearly meetings of Colombian Indigenous communities that

\footnotetext{
4 The research team gathered important lessons from its application of a peer methodology in the specific Colombian Indigenous contexts we explored. Those lessons led to important theoretical reflections on matters related to access, ethics, and power distribution. In another, forthcoming article, we describe our findings regarding the potentialities, shortcomings and usefulness of peer methodology within green, southern and Indigenous criminologies.

5 As we explain below, the four Indigenous peoples included in our study have political authority systems that rely on "elders" or "knowledgeable grandfathers." Communities assign those labels to individuals in acknowledgment of their life trajectories and their contributions to the community. Whereas there are clear links with age, the title "elder" does not exclusively depend on it.
} 
are held to remind the government of its promises and in which representatives of several Colombian communities discuss Indigenous cosmovisions.

The project methodology complied with Colombian legal requirements concerning research ethics (Resolution 0843 of $1993^{6}$ ) and we obtained informed consent from all interviewees. We explained the purpose of the project, obtaining first oral consent, in Spanish or in the relevant Indigenous language, when required, and we also provided printed information materials and time for participants to read them. Interviews were recorded and transcribed by the peer researchers.

\section{Context: The Colombian Indigenous Peoples}

There are 102 Indigenous peoples in Colombia. With roughly 1.9 million individuals, they comprise around $3.3 \%$ of the total population. Until $2010,78 \%$ of them lived in rural areas, but in the last decade. a significant number have moved to urban areas due to internal armed conflict in Colombia and increasing territorial unsustainability. According to some commentators (see, e.g., Rodríguez 2015), the Colombian legal framework is one of the most advanced in the world in terms of multiculturalism, based on the Political Constitution of Colombia of 1991 (Constitución Política de Colombia de 1991) and its ratification of the Indigenous and Tribal Peoples Convention, 1989 (an International Labour Organization Convention, known as "ILO Convention 169" or "C169"), promising all Indigenous people in the country access to "[formal] education, health services, nutrition, and basic sanitation" (Rodríguez 2015: 2). Nevertheless, despite these measures, the Colombian government is still neglectful and life in Indigenous communities can involve dramatic suffering (Rodríguez 2015).

The Bari people live in the rain forests of Colombia and Venezuela around the central and eastern mountains of the Venezuelan Andes. Historically, they inhabited the evergreen tropical rainforests. The flora and fauna in these forests are similar to those of the Amazonian rainforest, only less diverse. Traditionally, the Barí were semi-nomadic, moving between longhouses, ${ }^{7}$ from one to another, depending on the season (Beckerman and Lizarralde 2013). Their social structure was made up by independent "hearth groups" (nuclear families) with no central authority in the longhouse. These two characteristicstheir semi-nomadic living and their extended social system-helped the Barí survive the attacks of colonizers and exposure to epidemic diseases. The most recent Colombian official census, conducted in 2005, reported 5,923 Barí persons in Colombia, ${ }^{8}$ and the last Venezuelan census from 2011 registered 2,831 Barí in Venezuela. $^{9}$

The Nasa people inhabit the Tierradentro territory, about $1400 \mathrm{~km}^{2}$ in size and located in the Colombian department of Cauca in the southwestern part of the country. The most important geophysical characteristics of this territory are its diversity, land instability and

\footnotetext{
${ }^{6}$ Retrieved on July 10, 2021, from https://www.urosario.edu.co/Escuela-Medicina/Investigacion/Docum entos-de-interes/Files/resolucion_008430_1993.pdf.

${ }^{7}$ Longhouses are undivided communal dwellings with capacity for "over fifty residents, with room for a similar number of visitors" (Beckerman \& Lizarralde 2013: 4-5). They are built "like a keeled half watermelon sliced from end to end lying with the flat side down" (Beckerman \& Lizarralde 2013: 4-5).

${ }^{8}$ Retrieved on July 10, 2021, from http://www.mincultura.gov.co/prensa/noticias/Documents/Poblaciones/ PUEBLO\%20BARI.pdf.

9 Retrieved on July 10, 2021, from http://www.ine.gov.ve/documentos/Demografia/CensodePoblacionyViv ienda/pdf/ResultadosBasicos.pdf.
} 
hilly landscape, which varies in altitude from 900 to 5,000 m above sea level. The Nasa comprise the largest Indigenous population of Colombia, with 118,845 persons counted in the 2005 census, thereby comprising $16.93 \%$ of the Indigenous population of the country. The traditional language, Nasa Yuwe, is still spoken by about $74 \%$ of the population (Ávila Martínez 2011). The Nasa community is structured around "elders" and shamans, who are the authorities in the community. Administratively, the Cabildos (community council) represents the community to the state, administers the lands and labor, and oversees the system of justice and punishment. The Nasa gained the right of self-governance of their Resguardos ${ }^{10}$ in the eighteenth century, under the leadership of Juan Tama (discussed below), although with Colombian independence in 1810, they faced new pressures, as a new squirearchy tried-sometimes successfully - to colonize the Indigenous lands. In the beginning of the twentieth century, the Nasa leader, Manuel Quintín Lame, asserted that "the land belongs to the Indigenous ... the almighty judge [nature] gave them to our first parents ...but later some ambitious guests took by force our beautiful gardens" (Quintín Lame 1971: 21), and led an insurgent indigenous movement that successfully positioned the Cabildos as autonomous Indigenous authorities (Ávila Martínez 2011).

The Ticuna live on the Colombian Amazon trapezoid, bordering Peru and Brazil, in territory covering approximately $900 \mathrm{~km}^{2}$. They are the largest group of Indigenous people in the Colombian Amazon region, with a 2005 census count of 7,895. ${ }^{11}$ Their territories are subject to diverse legal agreements and designations, for example, as national parks, forest reserves, Indigenous Resguardos, and Indigenous settlements not yet recognized as Resguardos. A Cabildo is the administrative authority of the Resguardos, and the Curaca is the highest authority of the Cabildo. The presence of the Colombian state on their territories is minimal, with the provision of education representing its assertion of sovereignty over the territory, and oversight of this function delegated to the Catholic church. Currently, the Colombian government is the main source of "formal" employment, but most Ticuna derive their income from the use of nature (Riaño Umbarila 2003).

The Uitoto $^{12}$ of the Amazon, who numbered around 100,000 at the beginning of the 1900 s, were one of the most numerous Indigenous communities inhabiting the region (Santamaría 2017). By 1987, however, only 5000 remained (Riaño Umbarila 2003), although their numbers increased to 6,444 at the time of the 2005 census. ${ }^{13}$ Like the Ticuna, the Uitoto traditionally lived in shared family malokas (a longhouse), although today, only the elders have malokas. The Uitoto still preserve a social structure in which the elders act as the chiefs of the community, having the role of preserving and transmitting the community's oral knowledge (Asociación Zonal Indígena de Cabildos y Autoridades Tradicionales de La Chorrera. (AZICATCH) 2006). This oral tradition is fundamental to maintaining the social fabric of the Uitoto: it is the chief of each of the 84 groups who "has the word" to rule the community and maintain peaceful relationships with the other groups. Ruling powers are still inherited based on ancestry.

\footnotetext{
10 A "Resguardo" is a legal recognition of the mandates of the C169 Convention allocating to a community the ownership of the land(s) it has inhabited historically.

11 Retrieved on July 10, 2021, from http://www.mincultura.gov.co/areas/poblaciones/noticias/Documents/ Caracterizaci\%C3\%B3n\%20del\%20pueblo\%20Tikuna.pdf.

12 Researchers have suggested using the term, Murui-Muinane, for these peoples as their enemies, the Caribe, used the term, Huitoto, as a pejorative. The Uitoto people themselves, however, decided in 1990 to use this name with a revised spelling (Candre and Echeverri 2008).

13 Retrieved on July 10, 2021, from https:/www.mininterior.gov.co/sites/default/files/upload/SIC/Puebl osIndigenas/pueblo_uitoto.pdf.
} 
Despite the differences between these communities in terms of their geographical location, form of social organization, and historical trajectory, they all share certain cultural representations of nature that are suggestive of ways of confronting and preventing environmental threats and harm. These ways of facing the world-and the possible lessons for other societies - are discussed in the next part.

\section{Findings}

All four groups of Indigenous people that we studied have environmental ontologiesbased on stories, narratives, images - in which (1) human well-being is dependent on, or influenced by, the actions of nonhuman animals and the spirits of the jungle (plants and trees); and (2) all components of nature, not only humans, have a mystical, deeply spiritual story to be told, which means that humans should consider them sacred. The characteristics we have noted in Indigenous environmental ontologies stand in stark contrast to the dominant modernist, Western environmental ontology in at least three main ways in that the latter (1) is anthropocentric (see, e.g., Sollund 2012); (2) dissociates nature from spirituality, regarding it as a "machine" (Bauman 2000); and (3) rejects mysticism, understood as the ways of expressing the belief that there is a hidden meaning to, or underpinning of, life (Hoyos Vásquez 2006). Of course, Western culture is not monolithic and there are many ways in which perspectives that value interconnections between humans and other beings in nature are embraced. But the dominant modern environmental ontology is most evidently a different world view to that of the Indigenous peoples described here.

We have identified two traits, which contain three differences between Indigenous environmental and modern Western ontologies (the latter being anthropocentric, non-spiritual, and skeptical). We argue that these differences, on the one hand, mean that Indigenous ontologies encourage respect for non-human components of nature, while on the other hand, Western ontologies provide an easing of restraint toward environmentally destructive behavior. We illuminate these differences for each trait using excerpts from our interviews, written records of the myths and legends of each of the four Indigenous peoples, and a link to the practices that they prompt. Due to a lack of space, we can provide examples of each trait in the environmental ontologies of only one or two Indigenous communities, but both traits are present in all four Indigenous peoples studied.

\section{The Well-Being of Humanity is Connected with the Well-Being of all on Earth}

The Barí cosmogony — or story of origin—as narrated by Barí elders and community leaders, reflects the idea that human existence is dependent on collaboration with non-human animals and the spirits of the jungle. Such collaboration seeks to heighten the positive effects of the symbiotic human-nature relationship, while minimizing negative impacts. Our interviewees told us the story of the creation of the universe: Sabaseba [the god-creator of life] created six skies and placed the Earth on the fifth of these. Sabaseba then put in place a liana along which the spirits of the nonhuman animals, rivers, trees and all other beings came down to Earth. Sabaseba then laid an egg on Earth from which thousands of 
small colorful snakes-some with wings-emerged and traveled in all directions. ${ }^{14}$ The snakes were beautiful, but envious, so they prevented any other being from existing on Earth. Sabaseba next created jaguars, who were powerful enough to control the snakes and thus make it possible for other beings to live on Earth. Human beings came to earth later, when Saymadoyi [the spiritual ancestor of the Bari] cut two pineapples from which a woman and a man emerged, one from each. These humans are the ancestors of the Bari people.

The Bari still recognize that had it not been for the help of jaguars and the Ichigbrin [spirits of the jungle], they would not have a territory and would not exist. Therefore, once the Bari emerged from the pineapple, Sabaseba directed them to take care of nature and to be in constant contact with the Ichigbrin. The Sadau [elders] carry and transmit this message orally to new generations. Barí identity effectively revolves around that cosmogony: they identify themselves as children of the jungle in permanent beneficial contact with the spirits of the nonhuman animals, rivers, trees, and winds.

The logic behind this first trait is a central component of the system of guidance and norms to which the Barí adhere regarding how humans should relate to nature. Consequently, rather than adapting nature to their needs, the Bari adapted to their natural circumstances by surviving without destroying their surrounding ecosystems. Beckerman and Lizarralde (2013: 83) remark that "in traditional times [the] nutritional demands [of the Barí] constituted no threat to the natural environment." The Barí did not aim to achieve a surplus of food. As such, they did not fish or hunt for any more than they needed to survive. They might even consume meat that was slightly rotten to avoid having to discard it. Three quarters of their individual food intake comes from horticultural crops (mainly manioc), one sixth from fish, and the rest from game and fruits (Beckerman and Lizarralde 2013). In addition, the Bari do not claim individual property over the land they inhabit, but only over the plants each member of the community plants. For the Bari, all components of nature are sacred; it is impossible for the Bari to own the water, the wind, the land or the nonhuman animals; these all have spirits. The Barí vow never to destroy ecosystems, and never to commercialize the land. Consequently, the climate, flora and fauna of the natural environment they inhabited remained constant for at least a millennium until the 1920s when colonizers, with an opposing ontology, started to clear lands on a large scale for livestock grazing (Beckerman and Lizarralde 2013). Because of the environmental ontologies that guide their lifestyle (and despite this external intervention), their relationship with nature is based on a cultural perspective that prevents the excesses and exploitation that might be considered "environmental crime."

\section{(Many) Indigenous Cosmologies Explain the Importance of and Consider Sacred all Components of Nature}

The Uitoto and Ticuna share the belief in spirits of nature, and the view of nature as their mother is also predominant. For example, they say that they come from a Whole- "there, on the hill, lies Komimafo [the Origin Whole]"- a Uitoto elder told us when sitting near the mythical place-"where Jitóma (the sun) and his brother Kécha were sitting." "One night, people started coming out of the Whole, but they had a tail as tadpoles, that is very

$\overline{14}$ For the myth of Sabaseba, see Crooke Ellison (2018), which is the only Barí myth available in print. 
clear to me. Jitóma and Kpecha cut the tail out of the people with the bigi" [ancestral machete]. ${ }^{15}$ This story implies that there were other beings on earth before the humans, and those beings have spirits that "talk to each other, the one says 'aaaaahhhyy!,", the other replies 'fifififififi!,' and then the wind comes; and the wind is the one that protects the jungle" (interview). The wind, with its powerful lungs, screams "oooo.aaaa.oooo" and this is recognized as the materialization of the spirits of the Amazonian rainforest (see López 2013).

The interpretation of this narrative has meant that the Uitoto and Ticuna should not buy, sell or rent the land because the land is the personification of their mother. Inhabitants of the Uitoto territories can sell only that which they have harvested. With respect to the spirits of the jungle, before traveling to the different places of the rainforest, these communities command that "you have to ask for permission, because each territory has its owner": it is the spirits of nature who own the jungle and who materialize in the wind. One interviewee explained that "the Indigenous protect nature, because otherwise diseases come, the winds come, therefore protecting nature is good for us." "Wildlife" may be caught and killed only for nutrition: "other than that is not allowed, we cannot touch it." This practice, although problematic in terms of the spirit of the "wildlife," is enacted due to perceived real nutritional needs. That said, it tries to achieve a balance that respects nature and affects the ecosystems as little as possible. Again, such a relationship with nature and a view of other species as connected beings has provided a form of cultural harm or crime prevention that rejects excessive use or exploitation.

Similarly, the Nasa use the story of their origin as a reference for the building and sustenance of their communitarian identity. Our interviewees told us that the Nasa come from the water, as it was the water who gave them Khwen Tama (also referred to as Juan Tama). The story of Khwen Tama is half true and half myth, but the Nasa embrace it in its entirety. In the story, a heavy storm occurred one night, frightening all in the human community of the affected area. The day after, when the storm was over, the community saw that their territory had a new river-and floating on the surface was baby Khwen Tama. They then understood that a star was the mother of Khwen, and that Khwen, himself, had descended from the sky and come to Earth through the Pataló Lagoon. ${ }^{16}$ When Khwen grew up, he married Mandiguagua - at the time when the Nasa were involved in a bloody war with the Spanish invaders in the early 1700s. Khwen was horrified to see that the Spaniards wanted to divide and destroy Mother Earth, so he led the Nasa to claim sovereignty over their lands. He then governed the Nasa people and taught them that "a Nasa without their territory is nothing" (interview). Once he was old and believed his community to be wellorganized, he went back to the Pataló Lagoon, and through it, he reunited with his mother, the star. ${ }^{17}$

Reflecting the second trait of Indigenous environmental ontologies, the narrative of Khwen Tama is both a source and an illustration of the idea of Mother Earth used by the Nasa. ${ }^{18}$ A common mantra for the Nasa is "from the earth we come and to the earth we go.” Khwen Tama came through a lagoon and went back to it when he grew older. For the

\footnotetext{
15 For the full story of the "Whole," see Kuiru Naforo, Jitóma, Berrío, Vivas Hurtado, and Londoño (2017).

16 This Lagoon is currently known as the Juan Tama Lagoon. It is located at the north of the Cauca Department. Many of the main Nasa ceremonies take place near this lagoon.

17 For more about the legend of Khwen Tama, see López (2013); Solarte Lindo (1997); Yonda Canencio (2014).

18 The concept of Mother Earth does not appear in the Barí culture.
} 
Nasa, their most important identity trait is to have a balanced interaction with all elements of nature. The bond the Nasa have with the Earth prompts them to seek harmony with life; this, too, results in a culturally inspired form of prevention of environmental harm and crime. The Nasa environmental ontology guides people to avoid a hierarchical relationship with nature; there is no private property within Nasa territory and the lands are collective: the Cabildo assigns lands to families to inhabit and harvest, usually growing corn, sugarcane and various vegetables (Ávila Martínez 2011). Furthermore, the idea of harmony underpins all daily activities of the Nasa. They seek harmony with nature every day, and most visibly, during the rituals that express harmonization with nature. The Nasa have three major rituals_-sek buy, sakelo and chapus_-during which they build a spiritual relationship with the elements of the Earth (air, fire, soil and water); these rituals also have the function of keeping alive the Nasa environmental ontology. Harmony, for the Nasa, is the capacity to "convivir and sobrevivir" [live together and survive]. The Nasa use the concept of harmony to guide their interactions with nature and reject any classification or ranking of species believing "there is no differentiation because it is a common relationship, a collective relationship, it is a spiral."

\section{Discussion: Cultural Constructions and Questions of Practice}

The accounts presented above are, obviously, only a simplified version and explanation of the common traits of the environmental ontologies of the four Colombian Indigenous peoples we studied. Nevertheless, they are valid illustrations of some of the beliefs and messages within these cultures that are conducive to encouraging the protection of nature. The four peoples we studied can present their view of the ideal ways in which humans should behave: by the prohibition against selling their land; the invitation for people to adapt to nature rather than the other way around; the warning of the importance of asking permission from nature before intruding on her; and the ban on killing animals for purposes other than survival.

Where the lessons we may learn from these ideal principles require further reflection arises in considering responses to deviations from the ideal. As in every society, some members of these peoples will also stray from these ideal behaviors-in many cases, due to external interference or influence. Furthermore, these peoples also engage in practices that contradict the principles or expectations of animal rights movements, such as using "wildlife" for traditional medicines. Nevertheless, we would argue that their relationship with nature is based on a much sounder affinity and respect for nature than dominant Western society.

We argue that these narratives can be the basis for practical applications in challenging anthropocentrism - the ideology that bases its worldview on human notions of value, thereby turning nature into mere "resources" or "services" for the satisfaction of human desires (Sollund 2019) — and that these narratives can contribute to the prevention of environmental crimes and harms. The environmental ontologies described constitute systems of guidance and norms for daily behavior. These are also present in the communitarian practices of punishment within these communities. Upon breaches of expected environmental norms, individuals are taken to the community's assembly, which adjudicate the case. The sentence for an act, such as burning fields, is usually community service, but more serious cases may, in some communities, result in harsh penalties—such as whipping 
and exile ${ }^{19}$ - largely symbolic but powerful in effect. Extreme violations of the environmental ontology — such as killing a bear-are forwarded to the state's penal system, which may result in imprisonment.

There have been questions and criticisms concerning how "usos y costumbres" (practices and customs) such as these should be applied and, in the case of corporal punishments (use of the stocks or public whipping), disputes have occurred as to whether such punishments can be seen as "traditional" given their origins in Spanish colonial rule. Despite such criticism (partly arising from the youth of some communities), Rappaport (2003: 333, 335) suggests that "their traditional nature is ensured by their place within a coherent cosmovision" although, as Rappaport continues:

the interpenetration of Nasa cosmovisión with the legal and constitutional worldview of the dominant Colombian society is highly problematic when it is put into practice on the ground. Processes of cultural construction, which work so well in opening inter-ethnic dialogue, in expanding the space of intercultural collaboration, and in galvanizing cabildos to extend their autonomy, must be framed in practical procedural models that have not yet been clearly formulated.

A full analysis of the Indigenous administration of justice in environmental realms would require more space (for an in-depth examination, see Hernández Terán 2017), and practices such as whipping (even if symbolic) and exile, demand more extensive debate. The linking of environmental "offending" with harsh punishments does, however, signal that-as opposed to the situation in most Western countries (Sollund and Runhovde 2020)—Indigenous environmental ontologies take such offenses very seriously within the system of administration of justice.

\section{Conclusion}

In this article, we have endeavored to propose a 'southern green cultural criminological' approach to environmental crime prevention based on Indigenous knowledge and practices. We argue that despite widespread human awareness of the environmental harms we are causing on a daily basis, we succumb to the overwhelming abundance and influence of powerful capitalist cultural messages that carry social expectations of conformity and lead us to engage in environmentally unsustainable practices (see also Agnew 2013).

Our argument in response is that a protective environmental ontology can inspire a respectful relationship with nature. To substantiate our claim, we have reported on an exploratory study of four Colombian Indigenous peoples and their environmental ontologies. These can be characterized, first, by an assertion that human well-being is dependent on the actions of non-human animals and spirits of the jungle; and, second, by treating nature as a whole as sacred. We found an association between these environmental ontologies and the protective and praiseworthy behaviors toward nature within these communities. Preserving these ontologies encourages environmentally friendly human interactions with the natural world. A challenge for green criminology is, first, how to determine ways in which these ontologies can be used in broader settings and, second, how to help prevent

${ }^{19}$ Of the four communities that we studied, only the Nasa engage in whipping. 
the socio-economic dynamics that are leading to the erosion of the way of life of these Indigenous communities.

In this article, we do not propose explicit policies that authorities can simply take from the example of Indigenous cultural representations of nature. Crime prevention measures must reflect the specificities of the context in which they are applied. It is, therefore, a matter for local or national authorities to evaluate how to transpose the protective elements of Indigenous environmental ontologies to their own strategies for the governance of crime prevention efforts and environmental preservation. The application of a development ethnography is an ideal tool for such a purpose and, as attempted here, can shed light on how the knowledge held and produced by oppressed and minority groups can be used in social policy to minimize social and environmental harms (Escobar 2011; Goyes 2020).

Acknowledgements Financial support was provided by Northumbria University's Global Challenges Research Fund Internal Scheme, and by the stimuleringsmidler fund from the Department of Criminology and Sociology of Law, University of Oslo. We thank the two anonymous reviewers for providing feedback useful in improving this article.

Funding Open access funding provided by University of Oslo (incl Oslo University Hospital).

Open Access This article is licensed under a Creative Commons Attribution 4.0 International License, which permits use, sharing, adaptation, distribution and reproduction in any medium or format, as long as you give appropriate credit to the original author(s) and the source, provide a link to the Creative Commons licence, and indicate if changes were made. The images or other third party material in this article are included in the article's Creative Commons licence, unless indicated otherwise in a credit line to the material. If material is not included in the article's Creative Commons licence and your intended use is not permitted by statutory regulation or exceeds the permitted use, you will need to obtain permission directly from the copyright holder. To view a copy of this licence, visit http://creativecommons.org/licenses/by/4.0/.

\section{References}

Adams, K.A., \& Lawrence, E.K. (2019). Research Methods, Statistics, and Applications (Second ed.). London: Sage.

Agnew, R. (2013). The ordinary acts that contribute to ecocide: A criminological analysis. In N. South \& A. Brisman (Eds.), Routledge International Handbook of Green Criminology (pp. 58-72). Abingdon, Oxon, UK, and New York: Routledge.

Amster, R. (2019). From Peacemaking to Peacebuilding Criminology. Critical Criminology: An International Journal, 27(1), 73-84. https://doi.org/10.1007/s10612-019-09442-y

Apaza Huanca, Y. K. (2019). Non-wester epistemology and the meaning of the Pachamama (environment) within the world(s) of the Aymara identity. International Journal for Crime, Justice and Social Democracy, 8(3), 6-22.

Ávila Martínez, A. (2011). El pensamiento de la comunidad Nasa Yuwe: Un acercamiento al mundo de la vida y una reflexión acerca de su pensamiento [The thought of the Nasa Yuwe community: an approach to the world of life and a reflexion about their thought]. Bogotá: Universidad Cooperativa de Colombia.

AZICATCH. (2006). Plan de vida y de abundancia de los Hijos del Tabaco, la Coca y la Yuca Dulce de la Chorrera [Plans for life and abundance of the Sons of Tobacco, Coca and Sweet Cassava from la Chorrera]. La Chorrera: Asociación Zonal Indígena de Cabildos y Autoridades Tradicionales de La Chorrera.

Bauman, Z. (2000). Modernity and the Holocaust. Ithaca, NY: Cornell University Press.

Beckerman, S., \& Lizarralde, R. (2013). The Ecology of the Barí. Rainforest Horticulturalists of South America. Austin, TX: University of Texas Press.

Biffi, E., \& Pali, B. (Eds.). (2019). Environmental Justice Restoring the future. Towards a restorative environmental justice praxis. Leuven: European Forum for Restorative Justice.

Boas, F. (2012). The mind of primitive man. London: Forgotten Books. 
Borges, H., \& Martín, T. (2015). The Mexican Town that bashes piñatas full of live animals. VICE, May 19. Retrieved on July 9, 2021, from https://www.vice.com/en_uk/article/kwzjea/yucatan-animal-sacri fice-tradition-876.

Brisman, Avi, and Nigel South. 2013. A green-cultural criminology: An exploratory outline. Crime Media Culture 9(2): 115-35.

Brisman, A., \& South, N. (2014). Green Cultural Criminology, Constructions of environmental harm, consumerism, and resistance to ecocide. Abingdon, Oxon, UK, and New York: Routledge.

Brisman, A., \& South, N. (2015). An Assessment of Tonry and Farrington's Four Major Crime Prevention Strategies as Applied to Environmental Crime and Harm. Journal of Criminal Justice and Security (Varstvoslovje), 17(2), 127-151.

Brisman, A., \& South, N. (2020). Toward a green cultural criminology of the "South." In A. Brisman \& N. South (Eds.), The Routledge International Handbook of Green Criminology (2nd ed.). (pp. 624-637). Abingdon, Oxon, UK, and New York: Routledge.

Brisman, Avi, and Nigel South. In Press. Green cultural criminology: Exploring literary and Indigenous cultural narratives from Latin America. In M. de Nardin Budó, D.R. Goyes, L. Natali, R. Sollund and A. Brisman (Eds.), Introdução à criminologia verde: Perspectivas críticas, decoloniais e do Sul, São Paulo, Brasil: Tirant lo Blanch.

Brisman, A., South, N., \& Walters, R. (2018). Climate Apartheid and Environmental Refugees. In K Carrington, R. Hogg, J. Scott, \& M. Sozzo (Eds.), The Palgrave Handbook of Criminology and the Global South (pp. 301-321). Cham: Springer International Publishing.

Candre, H., \& Echeverri, J. A. (2008). Tabaco frío, Coca dulce [Cool Tobacco, Sweet Coca: Teachings of an Indian Sage from the Colombian Amazon]. Bogotá: Universidad Nacional de Colombia.

Carrington, K., Hogg., \& Sozzo., M (2016). Southern criminology. The British Journal of Criminology, 56(1), 1-20.

Coomber, R., \& South, N. (Eds.). (2004). Drug use and cultural contexts 'Beyond the west': Tradition, change and post colonialism. London: Free Association Books.

Crook, M., Short, D., \& South, N. (2018). Ecocide, genocide, capitalism and colonialism: Consequences for indigenous peoples and glocal ecosystems environments. Theoretical Criminology, 22(3), 298-317. doi:https://doi.org/10.1177/1362480618787176.

Crooke Ellison, I. (2018). Y de cómo las cosas llegaron a ser: mitos leyendas indígenas colombianas [And of how things got to be: Colombian Indigenous myths and legends]. Bogotá: Apidama Ediciones.

Cunneen, C., \& Tauri, J. (2017). Indigenous criminology. Bristol, UK: Policy Press.

Datta, R. (2019). Imprementation of Indigenous environmental heritage rights: an experience with Laitu Khyeng Indigenous community, Chittagong Hill Tracts, Bangladesh. AlterNative, 15(4), 309-320.

Descola, P. (2005). Ecology as Cosmological Analysis. In A. Surrallés \& P. García Hierro (Eds.), The land withing. Indigenous territory and perception of the environment (pp. 22-35). Copenhagen: International Work Group for Indigenous Affairs.

Effinghan, N. (2013). An Introduction to Ontology. Cambridge, UK: Cambridge University Press.

Welsh, B. C.,\& Farrington, D. P. (2012). Crime Prevention and Public Policy. In D.P. Farrington and B.C. Welsh (Eds.), The Oxford Handbook of Crime Prevention (pp.1-18). Oxford: Oxford University Press.

Frank, A. (2010). Letting stories breathe: a socio-narratology. Chicago, IL: University of Chicago Press.

Geilfus, F. (1994). El árbol al servicio del agricultor. Manual de agroforestería para el desarrollo rural [The tree to the service of the farmer. Handbook of agroforestry for the rural development]. Turrialba: enda-caribe.

Goyes, D. R. (2018). Green Criminology as Decolonial Tool: A Stereoscope of Environmental Harm. In K. Carrington, R. Hogg, J. Scott, \& M. Sozzo (Eds.), The Palgrave Handbook of Criminology and the Global South (pp. 323-346). London: Palgrave.

Goyes, D. R. (2019). Southern Green Criminology. A Science to End Ecological Discrimination. Bingley, UK: Emerald.

Goyes, D. R., \& South, N. (2017). 'Green Criminology before Green Criminology': Amnesia and Absences. Critical Criminology: An International Journal, 25(2), 165-181. https://doi.org/10.1007/ s10612-017-9357-8.

Hall, S. (1992). The West and the Rest: Discourses and Power. In S. Hall \& B. Gieben (Eds.), Formations of Modernity (pp. 184-227). Cambridge, UK: Polity Press..

Hernández Terán, M. (2017). Justicia Indígena, derechos humanos y pluralismo jurídico: análisis, doctrina y jurisprudencia [Indigenous justice, human rights and legal pluralism: analysis, doctrine and jurisprudence]. Bogotá: Gropo Editorial Ibañez.

Heydon, J. (2019). Sustainable Development as Environmental Harm. Rights, Regulation, and Injustice in the Canadian Oil Sands. Abingdon, Oxon, UK: Routledge. 
Higgins, P. (2010). Eradicating ecocide: Exposing the corporate and political practices destroying the planet and proposing the laws needed to eradicate ecocide. London: Sheapheard-Walwyn Publishers.

Hill, J. (2015). A systems thinking perspective on the motivations and mechanisms that drive wildlife poaching. In R. Sollund (Ed.), Green Harms and Crimes. Critical criminology in a changing world (pp. 189-219). Basingstoke, Hampshire, UK: Palgrave.

Hoyos Vásquez, G. (2006). Ciencia y ética desde una perspectiva discursiva [Science and ethics from a discoursive perspective]. Convergencia, 13(42), 117-131.

Kassam, K.-A. S. (2009). Biocultural diversity and Indigenous ways of knowing. Human ecology in the artic. Calgary, AB: University of Calgary Press.

Kuiru Naforo, J., Jitóma, N., Berrío, M., Vivas Hurtado, S., \& Londoño, S. (2017). Narraciones Indigenas de la Selva [Indigenous narrations from the jungle]. Bogotá: Norma.

López, J. O. (2013). Mitos y leyendas indígenas de Colombia [Colombian Indigenous myths and legends]. Bogotá: Plaza \& Janes.

Lushey, C. J., \& Munro, E. R. (2015). Participatory peer research methodology: An effective method for obtaining young people's perspectives on transitions from care to adulthood? Qualitative Social Work, 14(4), 522-537.

MacManus, T. (2016). The denial industry: public relations, 'crisis management' and corporate crime. The International Journal of Human Rights, 20(6), 785-797.

McClanahan, B., \& Brisman, A. (2015). Climate Change and Peacemaking Criminology: Ecophilosophy, Peace and Security in the "War on Climate Change." Critical Criminology: An International Journal, 23(4), 417-431. https://doi.org/10.1007/s10612-015-9291-6.

McGarrell, E. F., \& Gibbs, C. (2014). Conservation criminology. Environmental crime and risk. Oxford: Oxford University Press.

Norberg-Hodge, H. (2009). Ancient Futures: Lessons from Ladakh for a Globalizing World. San Francisco, CA: Sierra Club Books.

Quintín Lame, M. (1971). En defensa de mi raza [In defence of my race]. Bogotá: Publicaciones de la Rosca.

Rappaport, J. (2003). Redrawing the Nation: Indigenous Intellectuals and Ethnic Pluralism in Contemporary Colombia. In M. Thurner and A. Guerrero (Eds.), After Spanish Rule: Postcolonial Predicaments of the Americas (pp.310-346). Durham, NC: Duke University Press.

Rees, M. (2018). On the Future: Prospects for Humanity. Princeton, NJ: Princeton University Press.

Riaño Umbarila, E. (2003). Organizando su espacio, construyendo su territorio. Transformaciones de los asentamientos Ticuna en la ribera del Amazonas colombiano [Organising their space, building their territory. Transformations in the Ticuna settlings on the riverside of the Colombian Amazon]. Bogotá: Universidad Nacional de Colombia.

Rodríguez, G. A. (2015). Los Derechos de los Pueblos Indígenas de Colombia. Luchas, contenido y relaciones. Bogotá: Editorial Universidad del Rosario.

Rohe, W. (2012). Crime Prevention. In van Vliet (Ed) The Encyclopedia of Housing (2 ed.) (pp. 310-331). Thousand Oaks: Sage. doi:https://doi.org/10.4135/9781452218380.

Said, E. (1978). Orientalism. New York: Pantheon Books.

Sandberg, S., Tutenges, S., \& Copes, K. (2015). Stories of violence: a narrative criminological study of ambiguity. The British Journal of Criminology, 55(6), 1168-1186.

Santamaría, A. (2017). Memory and resilience among Uitoto women: closed baskets and gentle words to invoke the pain of the Colombian Amazon. Latin American and Caribbean Ethnic Studies, 12(3), 315330. doi:https://doi.org/10.1080/17442222.2017.1363352.

Solarte Lindo, F. (1997). El hombre con cola de león. Bogotá: Panamericana.

Sollund, R. (2012). Victimisation of Women, Children and Non-human Species Through Trafficking and Trade: Crimes Understood Under an Ecofeminist Perspective. In N. South \& A. Brisman (Eds.), Routledge International Handbook of Green Criminology (pp. 317-330). Abingdon, Oxon, UK, and New York: Routledge.

Sollund, R. (2019). The Crimes of Wildlife Trafficking. Issues of Justice, Legality and Morality. London: Routledge.

Sollund, R. A. and S. R. Runhovde (2020). Responses to wildlife crime in post-colonial times. Who fares best? The British Journal of Criminology, 60(4), 1014-1033.

South, N. (2007). The 'Corporate Colonisation of Nature': Bio-Prospecting, Bio-Piracy and the Development of Green Criminology. In P. Beirne \& N. South (Eds.), Issues in Green Criminology: Confronting Harms against Environments, Humanity and other Animals (pp. 230-247). Cullompton, Devon, UK: Willian. 
South, N., Brisman, A., \& Beirne, P. (2013). A guide to green criminology. In N. South \& A. Brisman (Eds.), Routledge International Handbook of Green Criminology (pp. 27-40). Abingdon, Oxon, UK, and New York: Routledge.

Stretesky, P. B., Long, M. A., \& Lynch, M. J. (2014). The Treadmill of Crime: Political Economy and Green Criminology. Abingdon, Oxon, UK, and New York: Routledge.

Tsering, T. (2008). The Green Primitives of the Himalayas Revisited. Diaspora, Indigenous, and minority education, 2(4), 295-301.

United Nations Development Programme. (n.d.). The SDGS in action. Retrieved on July 10, 2021, from from https://www.undp.org/sustainable-development-goals.

Vetlesen, A. J. (2019). Cosmologies of the Anthropocene. Panpsychism, Animism, and the Limits of Posthumanism. Abingdon, Oxon, UK: Routledge.

Verne, S. (2019). She must be civilized, she paints her toenails. In N. Greymorning (Ed.), Being Indigenous. Perspectives on Activism, Culture, Language and Identity (pp. 171-184). Abingdon, Oxon, UK: Routledge.

White, R. (2018). The global context of transnational environmental crime in Asia. In K. Carrington, R. Hogg, J. Scott, \& M. Sozzo (Eds.), The Palgrave Handbook of Criminology and the Global South (pp. 281-300). London, UK: Palgrave.

Wilson, E., \& Stammlet, F. (2016). Beyond extractivism and alternative cosmologies: Artic communities and extractive industries in unvertain times. The Extractive Industries and Society, 3(1), 1-8.

Wyatt, T. (2015). Invisible Pillaging: The Hidden Harm of Corporate Biopiracy. In P. Davies, P. Francies, and T. Wyatt (Eds.), Invisible Crimes and Social Harms (pp. 161-177). London: Palgrave.

Yonda Canencio, G. (2014). Juan Tama de la Estrella. Bogotá: Territorios Narrados PNLE.

Younging, G. (2018). Elements of Indigenous Style. A Guide for Writing By and About Indigenous Peoples. Edmonton, AB: Brush.

Publisher's Note Springer Nature remains neutral with regard to jurisdictional claims in published maps and institutional affiliations. 